\title{
Native woody plant recruitment in lowland forests invaded by non-native ground cover weeds and mammals
}

\author{
Kate G. McAlpine ${ }^{1 *}$, Shona L. Lamoureaux ${ }^{2}$, Susan M. Timmins ${ }^{1}$ and Debra M. Wotton ${ }^{1,3,4}$ \\ ${ }^{1}$ Department of Conservation, PO Box 10420, Wellington 6143, New Zealand \\ ${ }^{2}$ AgResearch Ltd, Private Bag 4749, Lincoln 8140, New Zealand \\ ${ }^{3}$ Present address: Moa's Ark Research, PO Box 11270, Wellington 6142, New Zealand \\ ${ }^{4}$ University of Canterbury, Private Bag 4800, Christchurch 8140, New Zealand \\ *Author for correspondence (Email: kmcalpine@doc.govt.nz)
}

Published online: 30 September 2016

\begin{abstract}
Globally, lowland forests have been depleted, fragmented, and degraded by land clearance and conversion by humans. Many remnants are also invaded by non-native plants and mammals, which can exacerbate biodiversity loss and impede ecosystem recovery. We examined the effects of non-native ground cover weeds and mammals on the seedling recruitment of native woody plants in lowland forests in northern New Zealand by following establishment over 2 years at sites experiencing different levels of weed cover, with or without supplemental seed addition, and with or without mammal exclusion. In general, native seedling recruitment was highest where seeds had been added and mammals excluded. Native seedling recruitment was negatively correlated with weed cover at sites invaded by Asparagus scandens or Tradescantia fluminensis, but only where seeds had been added. These results suggest that attempts to facilitate native seedling recruitment by sowing native seeds will be most successful where ground cover weeds and introduced mammals are low in abundance. Seedling recruitment was highest for Piper excelsum, Myrsine australis and Melicytus ramiflorus, so these species could be good options for lowland-forest restoration projects where ground cover weeds are present.
\end{abstract}

Keywords: ecosystem impacts; forest restoration; invasive alien species; invasive plants; pest animals; seedling recruitment; weed abundance

\section{Introduction}

Lowland forests have been severely depleted, degraded and fragmented the world over, largely due to land clearance and conversion by humans (Turner \& Corlett 1996; Jepson et al. 2001). In New Zealand, $71 \%$ of indigenous forest is gone, much of it from the accessible lowlands (Ewers et al. 2006; Walker et al. 2006). Remaining forest remnants typically have a suite of non-native plants and mammals present (Jane 1983; Timmins \& Williams 1991; Craig et al. 2000; King 2005), which can exacerbate biodiversity loss and impede ecosystem recovery (Didham et al. 2007; Hutchison 2008; Burns et al. 2011). Lowland forest remnants are particularly susceptible to invasion by non-native plants for several reasons. First, they tend to be close to human settlements, and thus to source populations of non-native plant species that 'escape' from gardens (Timmins \& Williams 1991; Sullivan et al. 2005). Additionally, they are usually subject to a high frequency of anthropogenic disturbance and have a high edge to interior area ratio relative to intact forest, both of which are associated with plant invasion (Brothers \& Spingarn 1992; Alston \& Richardson 2006; Wiser \& Allen 2006).

Invasive, non-native, shade-tolerant ground-cover plants (hereafter called ground cover weeds) can be particularly detrimental to native forest regeneration because they have the potential to alter forest structure, composition, and function (Wiser \& Allen 2006). Many form dense vegetative mats that smother native seedlings and reduce native plant abundance and diversity (Schulz \& Thelen 2000; Standish et al. 2001; Dlugosch 2005; McAlpine et al. 2015), potentially impeding native plant regeneration and succession. The extent to which weed impacts vary with weed abundance is not well understood.
However, it seems likely that the thicker the vegetative mat of a ground cover weed, the less likely it is that native seedlings will recruit or survive. Several New Zealand studies have examined this question for the ground cover weed Tradescantia fluminensis, and suggested that the most severe impacts on native regeneration occur when tradescantia is beyond a certain threshold of biomass (Standish et al. 2001; McAlpine et al. 2015). McAlpine et al. (2015) also demonstrated that two other species of ground cover weeds, Asparagus scandens and Plectranthus ciliatus, were associated with reduced native plant abundance and diversity, although a biomass threshold was less evident.

Where invaded forest remnants are isolated from other native habitat, seed dispersal limitation may further reduce native plant regeneration (McConkey et al.2012). If so, manual introduction of seed may be an effective management strategy to increase native seedling establishment (Honnay et al. 2002). Some native plant species may be better equipped than others to regenerate in the presence of ground cover weeds. For example, large-seeded species tend to have higher survivorship during establishment than small-seeded species, particularly in the face of hazardous conditions, such as competition from other vegetation (Moles \& Westoby 2004). On the other hand, large seeds may also be more susceptible to predation than small seeds, because bigger seeds are more conspicuous and offer greater food reward (Reader 1993; Gómez 2004). There are many biotic and abiotic factors that influence relative establishment success, so it is difficult to ascertain why any given species establishes more successfully than another. Nevertheless, it is useful for restoration purposes to determine which native plant species can successfully recruit from seed in the presence of common ground cover weeds. 
Non-native mammals that consume seeds and plants can also reduce native seedling recruitment (Reaser et al. 2007; Traveset et al. 2009; Murphy et al.2014). They can dramatically alter vegetation structure and prevent seedling regeneration, causing population declines - and even extinctions - of native plant species (Courchamp et al. 2003; Gurevitch \& Padilla 2004). Many studies have demonstrated an increase in native plant recruitment and/or growth following the exclusion or removal of introduced mammals, both in New Zealand (Allen et al. 1984, 1994; Wilson et al. 2003; Blick et al. 2008) and elsewhere (Weller et al. 2011; Cole et al. 2012). In New Zealand, non-native mammals such as brushtail possums (Trichosurus vulpecula), ship rats (Rattus rattus), red deer (Cervus elaphus scoticus), pigs (Sus scrofa), and goats (Capra hircus) are common in lowland forests (King 2005), and all can have negative impacts on the structure and diversity of the indigenous vegetation (Wilson et al. 2003; Spear \& Chown 2009; Grant-Hoffman et al. 2010; Krull et al. 2013). House mice (Mus musculus) are also common and, although their impacts on indigenous vegetation are unclear, they are known to consume indigenous flowers, fruits, seeds and seedlings in New Zealand (Murphy 1992; Ruscoe et al. 2004; Angel et al. 2009). Non-native mammals can sometimes have beneficial effects on indigenous vegetation, such as dispersing indigenous seed (Williams et al. 2000), or consuming and thus reducing weed biomass (Kessler 2002). Impacts can also vary according to the size and density of the animal population, environmental factors, and characteristics of the local vegetation (Wardle 1984; Allen et al. 2013).

Despite being degraded, fragmented and invaded by non-native plants and mammals, New Zealand lowland forest remnants often have considerable conservation value. This value is partly because of their rarity (Ewers et al.2006), but also because they tend to sustain far higher native biodiversity than the surrounding, typically highly modified, landscape (Burns et al. 2000). Better information about the impacts of invasive, non-native plants and mammals in these ecosystems will be useful to land managers seeking to conserve the biodiversity and improve the ecological integrity of these forest remnants. The objective of this study was to examine how native woody plant recruitment from seed in temperate New Zealand lowland forest remnants is affected by non-native ground cover weeds and mammals.

\section{Methods}

\section{Sites}

Six lowland forest sites where the ground layer vegetation (approx. $<500 \mathrm{~mm}$ height) was dominated by a single species of ground cover weed were identified in the Bay of Plenty area of the North Island, New Zealand (the same sites as in McAlpine et al. 2015). Two sites were found for each of three common ground cover weed species: Asparagus scandens (hereafter called climbing asparagus), Plectranthus ciliatus (hereafter called plectranthus), and Tradescantia fluminensis (hereafter called tradescantia). Sites were named as follows: asparagus 1 (abbreviated to Asp1), asparagus 2 (Asp2), plectranthus 1 (Ple1), plectranthus 2(Ple2), tradescantia 1 (Tra1), tradescantia 2 (Tra2). Across the six sites, mean annual temperature range is 9.9-18. $7^{\circ} \mathrm{C}$ and mean annual precipitation is $1436 \mathrm{~mm}$ (NIWA CliFlo database: http://cliflo.niwa.co.nz). Mean elevation ranged from 55 to $270 \mathrm{~m}$ a.s.l., latitude ranged from $37^{\circ} 25^{\prime}$ to $37^{\circ} 59^{\prime} \mathrm{S}$, and longitude ranged from $175^{\circ} 43^{\prime}$ to $176^{\circ} 02^{\prime} \mathrm{E}$.
All three weed species form dense, ground-covering mats of vegetation, and all can be associated with reduced indigenous abundance and species diversity in New Zealand lowland forests (McAlpine et al. 2015). Tradescantia is naturalised or invasive in at least 25 other countries around the world, and plectranthus and climbing asparagus are also invasive in Australia (Randall 2012). For further details of sites and weed species see McAlpine et al. (2015). All six sites were likely to have ship rats, brushtail possums and house mice present. Goats, red deer, pigs, hares (Lepus europaeus occidentalis) and rabbits (Oryctolagus cuniculus cuniculus) may have been present also. Additionally, livestock such as sheep and cattle may have breached fence boundaries occasionally. According to land managers, there had been very little, if any, pest animal control undertaken in recent years at any of the sites.

At each site, thirty-two $50 \times 50 \mathrm{~cm}$ plots stratified by percent of ground cover weed cover were established, eight for each of four cover classes: High ( $>95 \%$ cover), Medium (60-80\% cover), Low ( $20-40 \%$ cover), and Zero ( $<1 \%$ cover). Plots were situated beneath closed canopy forest, a minimum of $3 \mathrm{~m}$ from any forest edge, where non-native plant species other than the dominant ground cover weed species were absent. Additionally, plots were situated on flat or gently sloping ground, where the ground vegetation was no more than $30 \mathrm{~cm}$ high (to allow for mammal exclusion cages, see below). Each plot was divided in half, with the dividing line placed perpendicular to any slope of the ground, giving a total of 384 subplots.

Light availability was expected to be similar across plots, because they were all situated beneath closed canopy forest. During a previous experiment at the same six sites (McAlpine et al. 2015), measurements of percent canopy openness were made in order to quantify light availability. These measurements were made in 'high light' areas in canopy gaps and on forest edges, and in 'low light' areas beneath the closed canopy forest. The subset of measurements made in the low light areas (not previously reported in this way) are deemed applicable to the current study, because plots from the two studies were in close proximity, under the same intact forest canopies. In the previous study (McAlpine et al. 2015), photographs of the forest canopy were taken from approximately $1 \mathrm{~m}$ above the middle of 32 plots per site using a Canon EOS 50D digital SLR camera and $4.5 \mathrm{~mm}$ Sigma EX DC hemispherical (fisheye) lens. Photographs were then digitally analysed using HemiView image processing software (Delta-T Devices, Cambridge, UK).

\section{Native seed addition}

Fruits of ten common native lowland forest species were collected from remnant lowland forest populations in the Bay of Plenty and Coromandel areas. These species differ in shade-tolerance, but all are capable of establishing in the shade (Grubb et al.2013). Seeds of nine of the species were collected between November 2011 and February 2012, and seeds of a later fruiting species (Knightia excelsa) were collected in May 2012 (Appendix 1). Fruits were collected from a minimum of five plants per species. Fruit pulp was manually removed, then seeds were spread out to dry at room temperature. The number of seeds sown per species varied due to seed size and availability at time of collection (Appendix 1). In April 2012, the seeds of all species but $K$. excelsa were sown directly onto the soil in one randomly allocated half of each plot (subplot). Knightia excelsa seeds were added in June 2012. Where the ground sloped, seeds were sown towards the uphill edge of the subplot, and a straight stick was pressed into the ground on the 
downhill edge of the subplot to minimise seed displacement. Subplots were assessed in Jan 2012, before seed sowing, and 2 years later, in April 2014. In each subplot, percent cover of ground cover weed was estimated, and seedlings of the sown species with stem originating inside the subplot were counted.

Seeds of the native species were also sown in an unheated glasshouse to estimate seed viability. The number of seeds sown per species differed due to seed size and availability at time of collection (Appendix 1). Seeds were sown onto standard potting mix in $340 \mathrm{~mm} \times 285 \mathrm{~mm}$ plastic seedling trays in April 2012 (and June 2012 for $K$. excelsa), four replicate trays per species. Four additional trays of plain potting mix were included in order to monitor seed contamination from within the glasshouse. Trays were randomly arranged within four areas (one tray per species per area) of the glasshouse, and were kept continuously moist with frequent watering. Seedlings were counted, then removed, weekly for 7 months between May and December 2012. Germination had apparently ceased at the time of the final count (the last three seedlings were counted in mid-November), although it is possible that viable, dormant seeds remained in the soil. However, the seedling trays were inadvertently discarded in mid-December 2012, so no further monitoring was possible.

\section{Mammal exclusion}

In order to exclude mammals, closed-top cages were constructed from $19 \mathrm{~mm}$ aperture, stainless steel welded mesh, $60 \mathrm{~cm}$ square and $30 \mathrm{~cm}$ high. This mesh aperture was expected to exclude most mammals, excepting house mice and small rats (Tim Day, Xcluder ${ }^{\circledR}$ Pest Proof Fencing, unpubl. data). The caging treatment was randomly allocated to four of the eight plots within each of the four weed cover classes at each site (so 16 plots were caged and 16 plots were uncaged at each site). Following seed sowing, cages were placed over plots and pinned securely to the ground using a minimum of eight $13 \mathrm{~cm}$ galvanised steel pins per cage. Where necessary, a thin line of soil was slightly excavated around the plot edge so the cage edge fitted ground contours.

\section{Statistical analyses}

The total number of seedlings in subplots for all ten sown native species combined was modelled. Analyses were conducted in R v. 3.2.1 (R Core Team 2015) using the lme4 package (Bates et al.2014). First, whether percentage weed cover had a significant effect on native seedling abundance prior to the start of the experiment was tested. Seedling abundance in subplots was modelled using a Poisson generalised linear mixed-effects model (GLMM), with weed cover as a fixed effect and plot as a random effect (to account for the split-plot design). Sown native seedling abundance after 2 years was then modelled with site, weed cover, seed sowing, caging and the interactions between weed cover and seed sowing, and caging and seed sowing as fixed effects, and plot as a random effect. To assist interpretation of model coefficients, percentage weed cover was divided by the root mean square so that all predictors were on a common scale (Gelman \& Hill 2007).

Climbing asparagus cover was a significant predictor of native seedling abundance before the experiment (estimate $=$ -0.009207 , s.e. $=0.004614, \mathrm{z}=-1.996, P=0.046$ ). Therefore, data from the climbing asparagus sites were analysed using a Gaussian linear mixed-effects model with change in seedling abundance (number of seedlings at time zero minus number of seedlings after 2 years) as the response variable. For climbing asparagus, the plot random effect had a variance of zero, so data were reanalysed using a linear model without the random effect. Weed cover had no effect on the number of native seedlings prior to the start of the experiment for both plectranthus $(\mathrm{z}=-1.37, P=0.17)$ and tradescantia $(\mathrm{z}=-1.11$, $P=0.27)$. Therefore, data for these species were analysed using Poisson GLMMs with native seedling abundance as the response variable.

Plectranthus models that included weed cover failed to converge. An outlier subplot with 135 native seedlings after 2 years appeared to be unduly influencing the results and causing poor model fit to the data. To overcome these issues, data from plectranthus sites were analysed with only site, seeds, cage and the interaction between seeds and cage as fixed effects, and the outlier was removed. For plectranthus and tradescantia, marginal (variance explained by fixed effects) and conditional (fixed and random effects) $R^{2}$ (Nakagawa $\&$ Schielzeth 2013) values were calculated.

To test whether canopy openness differed significantly among the six sites, a beta regression model with variable precision was fitted using the betareg package (Cribari-Neto \& Zeileis 2010). Beta regression is suitable for modelling continuous data restricted to values between zero and one, such as canopy openness (Korhonen et al. 2007).

\section{Results}

\section{Climbing asparagus}

At the climbing asparagus sites, seed sowing had a significant effect on native seedling abundance after 2 years $(\mathrm{z}=3.04$, $P=0.003$; Fig. 1). There were more seedlings in subplots with seeds added $\left(114 \mathrm{~m}^{-2}, 0-632 \mathrm{~m}^{-2}\right.$, mean and range) than without seeds added $\left(30.63 \mathrm{~m}^{-2}, 0-184 \mathrm{~m}^{-2}\right)$. Caging to exclude

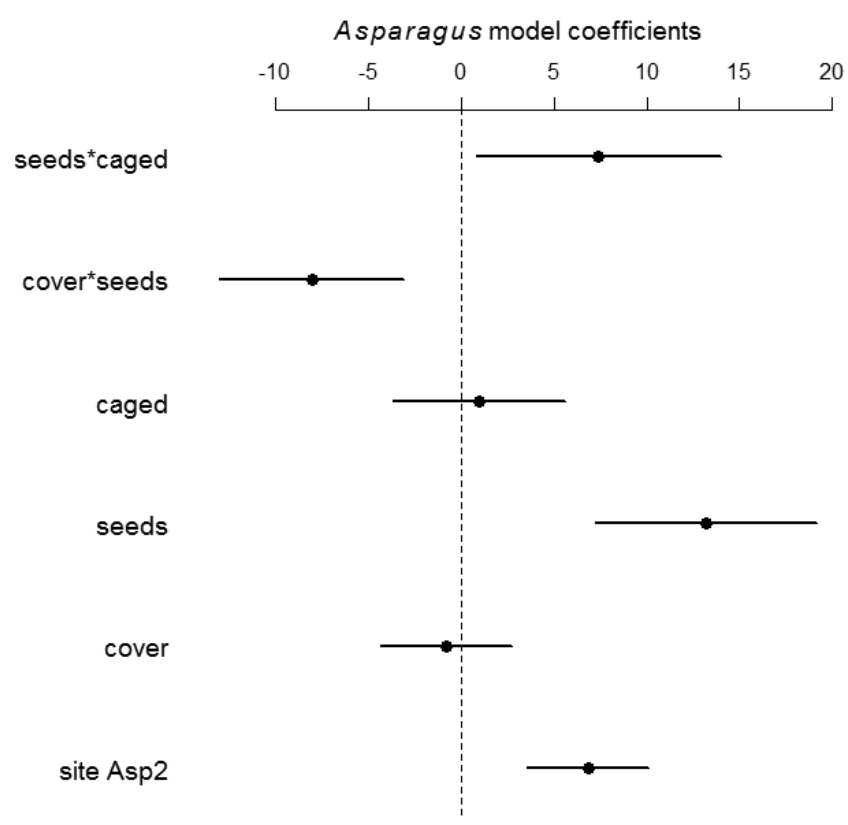

Figure 1. Estimated effects of site, climbing asparagus cover ('cover'), seed sowing ('seeds'), and caging ('caged') on change in sown native seedling abundance in subplots after 2 years at sites invaded by climbing asparagus. Points represent the mean estimates for seedling abundance and error bars are $95 \%$ confidence intervals. Where the $95 \%$ confidence interval excludes zero, predictors differ significantly from the intercept model (uncaged + no seed + weed percentage cover $=0+$ site $=$ Asp 1$)$. 
invasive mammals also significantly increased native seedling abundance, but only when seeds were added $(\mathrm{z}=2.21, P=$ 0.03 ; caged + seeds $=147.75 \mathrm{~m}^{-2}, 0-632 \mathrm{~m}^{-2}$; uncaged + seeds $=80.25 \mathrm{~m}^{-2}, 0-464 \mathrm{~m}^{-2}$ ). Likewise, there was a significant negative correlation between climbing asparagus cover and native seedling abundance after 2 years, but only when seeds were added $(\mathrm{z}=-3.15, P=0.002)$. There were significantly more native seedlings at site Asp2 than at site Asp1 after 2 years $(\mathrm{z}=4.08, P<0.0001)$. The model explained $42 \%$ of the variance in the data (adjusted $R^{2}$ ).

\section{Plectranthus}

At the plectranthus sites, caging increased native seedling abundance, but only when seeds were added $(\mathrm{z}=10.6, P<$ $0.0001 ;$ caged + seeds $=127.75 \mathrm{~m}^{-2}, 0-680 \mathrm{~m}^{-2} ;$ uncaged + seeds $=50.75 \mathrm{~m}^{-2}, 0-248 \mathrm{~m}^{-2}$; Fig. 2). There were significantly more seedlings at site Ple1 than at site Ple2 $(\mathrm{z}=-2.94, P=0.003)$. Fixed effects in the model explained $20 \%$ of the variance in the data, while fixed and random effects together explained $76 \%$. Hence, much of the variability in the data was due to differences among plots (the random effect).

\section{Tradescantia}

At the tradescantia sites, seed sowing and caging both had a significant effect on native seedling abundance after 2 years (seeds: $\mathrm{z}=4.31, P<0.0001$; caging: $\mathrm{z}=2.13, P=0.03$; Fig. $3)$. There were more seedlings in subplots with seeds sown $\left(46.75 \mathrm{~m}^{-2}, 0-264 \mathrm{~m}^{-2}\right)$ than without $\left(21.25 \mathrm{~m}^{-2}, 0-176 \mathrm{~m}^{-2}\right)$, and in caged $\left(47.25 \mathrm{~m}^{-2}, 0-264 \mathrm{~m}^{-2}\right)$ than uncaged plots $(20.75$ $\left.\mathrm{m}^{-2}, 0-176 \mathrm{~m}^{-2}\right)$. There was a significant negative correlation between tradescantia cover and native seedling abundance after 2 years, but only when seeds were added $(\mathrm{z}=-4.47, P$ $<0.0001)$. Fixed effects in the model explained $18 \%$ of the variance in the data, while fixed and random effects together explained $63 \%$ of the variance. Again, much of the variability in the data was due to differences among plots.

\section{Native seedling recruitment}

The native species with the greatest increase in seedling numbers 2 years after seed sowing were $P$. excelsum, $M$. australis and M. ramiflorus (Fig. 4). For most species, seedling numbers were highest in subplots where seed had been added and mammals excluded (Fig. 4). Knightia excelsa had a high number of seedlings present before seed sowing but, overall, had a decrease in seedling numbers over the 2 years (Fig. 4). Overall, recruitment success was variable across species, and was not predicted by seed size (Fig. 4).

Average percent seed germination of native species in the glasshouse ranged from $0 \%(H$. arborea) to $67.5 \%(K$. excelsa) (Appendix 1). The control trays of plain potting mix revealed no seed contamination.

\section{Canopy openness}

The average $( \pm \mathrm{SD})$ percent canopy openness under the intact forest canopy was: $14.3 \pm 2.7$ (Asp1), $12.7 \pm 2.8$ (Asp2), $10.2 \pm 2.2$ (Ple1), $7.5 \pm 1.1$ (Ple2), $7.5 \pm 1.1$ (Tra1), $9.2 \pm 1.5$ (Tra2). Canopy openness differed significantly among sites $(\mathrm{z}=-44.842, \mathrm{P}<0.0001)$. Site explained $62 \%$ of the variance in canopy openness (pseudo $R^{2}$ ).

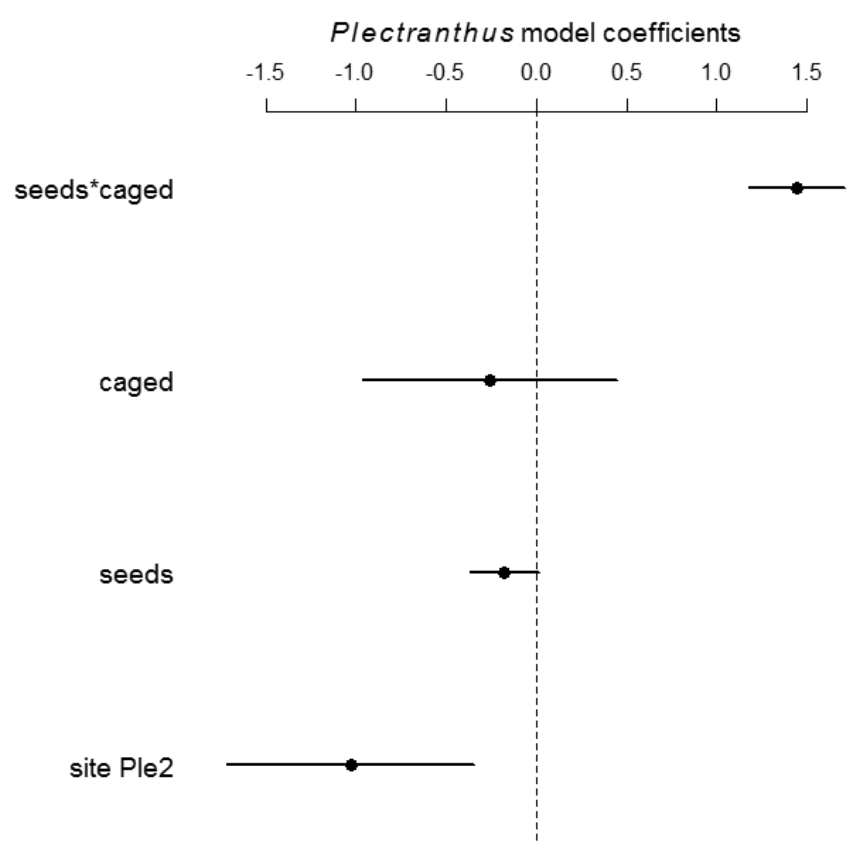

Figure 2. Estimated effects of site, seed sowing ('seeds'), and caging ('caged') on sown native seedling abundance in subplots after 2 years at sites invaded by plectranthus. Points represent the mean estimates for seedling abundance and error bars are $95 \%$ confidence intervals. Where the $95 \%$ confidence interval excludes zero, predictors differ significantly from the intercept model $($ uncaged + no seed + site $=$ Ple 1$)$.

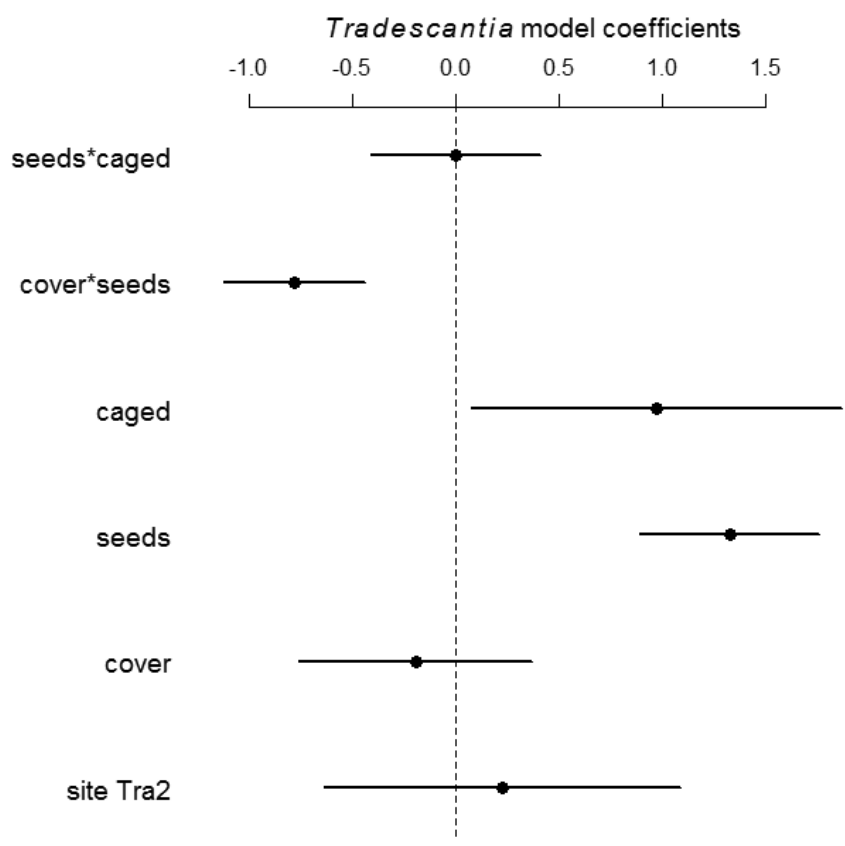

Figure 3. Estimated effects of site, tradescantia cover ('cover'), seed sowing ('seeds'), and caging ('caged') on sown native seedling abundance in subplots after 2 years at sites invaded by tradescantia. Points represent the mean estimates for seedling abundance and error bars are $95 \%$ confidence intervals. Where the $95 \%$ confidence interval excludes zero, predictors differ significantly from the intercept model (uncaged + no seed + weed percentage cover $=0+$ site $=$ Tra1 $)$. 


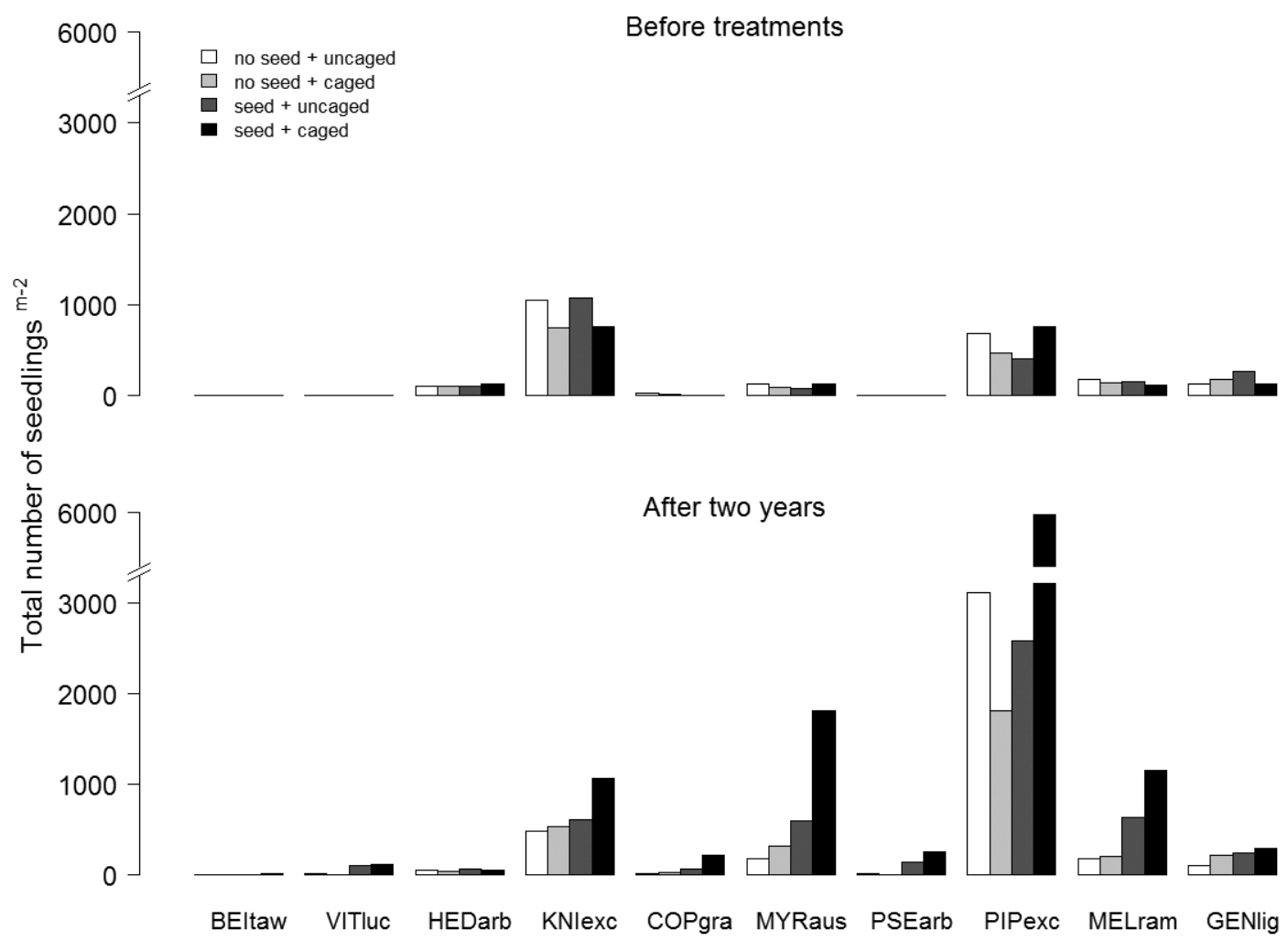

Figure 4. Total number of seedlings per $\mathrm{m}^{2}$ across all six sites ( $\mathrm{n}=384$ subplots), before, and 2 years after, seed sowing and caging treatments were applied. Species are ordered by seed size, from largest to smallest. BEItaw $=$ Beilschmiedia tawa, VITluc $=$ Vitex lucens, HEDarb = Hedycarya arborea, KNIexc $=$ Knightia excelsa, COPgra = Coprosma grandifolia, MYRaus = Myrsine australis, PSEarb $=$ Pseudopanax arboreus, PIPexc = Piper excelsum, MELram = Melicytus ramiflorus, GENlig = Geniostoma ligustrifolium. The number of seeds sowed per species varied, see Appendix 1.

\section{Discussion}

Sowing native seed can be an effective method of restoring native vegetation if rates of seed germination and seedling survival are high. In New Zealand, this method has been tested in lowland forest remnants (Overdyck et al. 2013), wetlands (Burge 2015), regenerating mānuka (Leptospermum scoparium) shrublands (Davis et al. 2013), and at sites invaded by woody weeds (Burrows et al. 2015; McAlpine et al. 2016). In all cases, sowing seed increased seedling numbers, indicating that native plant recruitment may be limited by seed and/or safe site availability (Duncan et al. 2009) in a wide range of ecosystem types in New Zealand. In the current study, seed addition generally resulted in higher numbers of seedlings, although recruitment was variable among species, and most species also recruited naturally from the seed rain or seed bank. Recruitment success did not appear to be related to seed size. Standish et al. (2001) also found seed size to be a poor predictor of native plant species abundance where tradescantia was present. Other factors, such as differences in shade tolerance (Standish 2002; Grubb et al. 2013), may be playing a role. For example, the lesser shade tolerance of $K$. excelsa could be a reason for its low seedling survival in the current study, particularly at the three sites where mean canopy openness was below $10 \%$, the suggested threshold at which a species that benefits from canopy openness might be disadvantaged compared with a shade-tolerant species (Lusk et al. 2013, 2015).
Piper excelsum, M. australis and $M$. ramiflorus had the greatest increase in seedling establishment following seed sowing, so these species could be good options for lowland forest restoration projects where ground cover weeds are at low to moderate abundance. All three species occur naturally in lowland forests throughout much of New Zealand (Wardle 1991), so are likely to be ecologically appropriate for restoration projects in many areas. However, in general, rates of seedling establishment in this study were low, although high mortality is typical of young seedlings (Fenner 1987). Potential causes of low germination and seedling establishment include the presence of plant pathogens, invertebrate seed/seedling consumers, and sub-optimal environmental conditions. Additionally, seeds can lose viability during storage, which, in the current study, was almost 5 months for some species. This situation was not ideal and, in general, best practice would be to sow seeds as soon as possible after collection, particularly for species with recalcitrant seeds, such as B. tawa (Knowles \& Beveridge 1982; Burrows 1989). Glasshouse germination results may have underestimated seed viability of species that have dormant or quiescent seeds, given that germination was only monitored for 7 months (Fountain \& Outred 1991; Burrows 1997).

Non-native mammals can have significant negative impacts on native vegetation in New Zealand (Campbell \& Rudge 1984; Wardle et al. 2001; Wilson et al. 2003). Results from the current study concur; excluding non-native mammals generally resulted in higher numbers of native seedlings. Four 
other New Zealand studies where mammals were excluded using similar mesh cages have yielded similar results. Wotton and Kelly (2011) demonstrated significantly higher native seed germination and seedling survival when mammals were excluded. Overdyck et al. (2013) showed that seeds and fruits accessible to mammalian seed predators suffered significantly greater loss $(58 \%)$ than those protected by cages $(4 \%)$. Burge (2015) found that protecting seeds and seedlings from predation and herbivory increased native seedling recruitment by more than $100 \%$. Wilson et al. (2003) monitored natural seedling establishment over 2 years, and reported 3.6 times more seedlings at one site where possums and rats had been excluded. In the current study, rats, possums and red deer are likely to be the main drivers of these effects because they are the species most likely to be present at all sites (Fraser et al. 2000; King 2005), and all have been shown to significantly reduce native seedling numbers through herbivory (Wilson et al. 2003; Husheer et al. 2006). Pigs and goats could also be reducing native plant cover, species richness and regeneration (Atkinson 1964; Campbell \& Donlan 2005; Krull et al. 2013), and seed predation by rats and mice could be reducing seedling establishment (Murphy 1992; Moles \& Drake 1999; Ruscoe et al. 2005; Overdyck et al. 2013). It is also possible that mammalexclusion cages have other positive impacts on native seedling survival, for example by providing additional shade or wind protection. Despite this growing body of knowledge on the effects of non-native mammals on native seedling establishment and survival in New Zealand, it remains uncertain how these impacts ultimately affect the structure and composition of native vegetation. Interestingly, a recent New Zealand study showed reduced establishment and growth of seedlings of some native woody plant species, in part because the biomass of grasses and sedges was greater (and may have reduced establishment by woody plants) when possums were excluded (Bellingham et al. 2016). If mammalian herbivores reduce biomass of climbing asparagus, plectranthus or tradescantia, the same may apply.

Results from the current study align with other evidence demonstrating that ground cover weeds can reduce native plant recruitment in New Zealand lowland forests, particularly when the weeds are abundant (Standish et al. 2001; McAlpine et al. 2015). Thus, removing or reducing the abundance of ground cover weeds may be conducive to native plant regeneration at sites where native seeds are present and environmental conditions are suitable for establishment. Additionally, controlling ground cover weeds in canopy gaps may also promote native plant recruitment, given that ground cover weed abundance can be positively correlated with light availability (Kelly \& Skipworth 1984; Standish et al. 2001; McAlpine et al. 2015). It is also conceivable that management effort given to increasing sub-canopy shade, for example by planting fast-growing, broad-leaved native species, could reduce ground cover weed abundance. This has previously been suggested as a method of suppressing tradescantia, and tested successfully using artificial shade cloth (Standish et al. 2001; Standish 2002). It remains to be seen whether shade from native plants introduced by sowing seed or planting seedlings could eventually reduce ground cover weed abundance.

In summary, this study has demonstrated that both ground cover weeds and non-native mammals can have negative effects on native plant regeneration in lowland forests. Thus, the management of one without regard for the other may have no net benefit for native plant regeneration. Attempts to facilitate native seedling recruitment by sowing seeds are likely to be most successful where ground cover weeds and introduced mammals are low in abundance.

\section{Acknowledgements}

This project was funded by the Foundation for Research Science and Technology (now Ministry of Business, Innovation and Employment) and Landcare Research Core Funding under the programme Beating Weeds II (C09X0905), and the New Zealand Department of Conservation. Thanks to Ian Nobel, Tim \& Heather Ryan, Ed \& Sue Harvey, Keith \& Denize Anderton, Chris Clark (Department of Conservation), Kerry Watson (Trustpower), and Greg Shaw (South Waikato District Council) for site access, and to Graeme Bourdot, Tom Belton, Sarah Crump, Simon Fowler, Sarah Jackman, Trevor James, Kris Kramer-Walter, Carrie Lusk, Brodi Muschamp, Walter Stahel, Mike Trolove, and Nancy van Nieuwenhove for other assistance. Comments from Peter Bellingham, Rachel Standish, Bruce Burns and Clayson Howell improved the manuscript.

\section{References}

Allen R, Payton I, Knowlton J 1984. Effects of ungulates on structure and species composition in the Urewera forests as shown by exclosures. New Zealand Journal of Ecology 7: 119-130.

Allen RB, Lee WG, Rance BD 1994. Regeneration in indigenous forest after eradication of Norway rats, Breaksea Island, New Zealand. New Zealand Journal of Botany 32: 429-439.

Allen RB, Bellingham PJ, Holdaway R, Wiser SK 2013. New Zealand's indigenous forests and shrublands. In: Dymond JR ed. Ecosystem services in New Zealand. Lincoln, Manaaki Whenua Press. Pp. 34-48.

Alston KP, Richardson DM 2006. The roles of habitat features, disturbance, and distance from putative source populations in structuring alien plant invasions at the urban/wildland interface on the Cape Peninsula, South Africa. Biological Conservation 132: 183-198.

Angel A, Wanless RM, Cooper J 2009. Review of impacts of the introduced house mouse on islands in the Southern Ocean: are mice equivalent to rats? Biological Invasions 11: $1743-1754$.

Atkinson IAE 1964. Relations between feral goats and vegetation in New Zealand. Proceedings of the New Zealand Ecological Society 11: 39-44.

Bates D, Maechler M, Bolker B, Walker S 2014. lme4: linear mixed-effects models using Eigen and S4. R package version 1.1-7.http://CRAN.R-project.org/package=lme4.

Bellingham PJ, Kardol P, Bonner KI, Buxton RP, Morse CW, Wardle DA 2016. Browsing by an invasive herbivore promotes development of plant and soil communities during primary succession. Journal of Ecology 104: 1505-1517.

Blick R, Bartholomew R, Burrell T, Burns KC 2008. Successional dynamics after pest eradication in the Karori Wildlife Sanctuary. New Zealand Natural Sciences 33: 3-14.

Brothers TS, Spingarn A 1992. Forest fragmentation and alien plant invasion of central Indiana old-growth forests. Conservation Biology 6: 91-100. 
Burge OR 2015. Facilitating forest recovery in Awarua wetland, Southland, New Zealand. Unpublished PhD thesis, University of Canterbury, Christchurch, New Zealand. 217 p.

Burns B, Barker GM, Harris R, Innes J 2000. Conifers and cows: forest survival in a New Zealand dairy landscape. In: Craig JL, Mitchell ND, Saunders DA eds. Nature conservation 5. Nature conservation in production environments: managing the matrix. Chipping Norton, Surrey Beatty \& Sons. Pp. 81-89.

Burns BR, Floyd CG, Smale MC, Arnold GC 2011. Effects of forest fragment management on vegetation condition and maintenance of canopy composition in a New Zealand pastoral landscape. Austral Ecology 36: 153-166.

Burrows C 1989. Patterns of delayed germination in seeds. New Zealand Natural Sciences 16: 13-19.

Burrows CJ 1997. Reproductive ecology of New Zealand forests: 1. Natural seed storage phenomena. New Zealand Natural Sciences 23: 31-52.

Burrows L, Cieraad E, Head N 2015. Scotch broom facilitates indigenous tree and shrub germination and establishment in dryland New Zealand. New Zealand Journal of Ecology 39: 61-70.

Campbell DJ, Rudge MR 1984. Vegetation changes induced over 10 years by goats and pigs at Port Ross, Auckland Islands (Subantarctic). New Zealand Journal of Ecology 7: 103-118

Campbell K, Donlan C 2005. Feral goat eradications on islands. Conservation Biology 19: 1362-1374.

Cole RJ, Litton CM, Koontz MJ, Loh RK 2012. Vegetation recovery 16 years after feral pig removal from a wet Hawaiian forest. Biotropica 44: 463-471.

Courchamp F, Chapuis J-L, Pascal M 2003. Mammal invaders on islands: impact, control and control impact. Biological Reviews 78: 347-383.

Craig J, Anderson S, Clout M, Creese B, Mitchell N, Ogden J, Roberts M, Ussher G 2000. Conservation issues in New Zealand. Annual Reviews in Ecology and Systematics 31: 61-78.

Cribari-Neto F, Zeileis A 2010. Beta regression in R. Journal of Statistical Software 34: 1-24.

Davis M, Henley D, Howell C, Coker G 2013. Establishment of Nothofagus solandri var. cliffortioides by seeding in Leptospermum scoparium shrublands. New Zealand Journal of Ecology 37: 139-145.

Didham RK, Tylianakis JM, Gemmell NJ, Rand TA, Ewers RM 2007. Interactive effects of habitat modification and species invasion on native species decline. Trends in Ecology \& Evolution 22: 489-496.

Dlugosch K 2005. Understory community changes associated with English ivy invasions in Seattle's urban parks. Northwest Science 79: 52-59.

Duncan RP, Diez JM, Sullivan JJ, Wangen S, Miller AL 2009. Safe sites, seed supply, and the recruitment function in plant populations. Ecology 90: 2129-2138.

Ewers RM, Kliskey AD, Walker S, Rutledge D, Harding JS, Didham RK 2006. Past and future trajectories of forest loss in New Zealand. Biological Conservation 133: 312-325.

Fenner M 1987. Seedlings. New Phytologist 106: 35-47.

Fountain DW, Outred HA 1991. Germination requirements of New Zealand native plants: a review. New Zealand Journal of Botany 29: 311-316.

Fraser K, Cone J, Whitford E 2000. Arevision of the established ranges and new populations of 11 introduced ungulate species in New Zealand. Journal of the Royal Society of New Zealand 30: 419-437.

Gelman A, Hill J 2007. Data analysis using regression and multilevel/hierarchical models. Cambridge, UK, Cambridge University Press. 625 p.

Gómez JM 2004. Bigger is not always better: conflicting selective pressures on seed size in Quercus ilex. Evolution 58: 71-80.

Grant-Hoffman MN, Mulder CP, Bellingham PJ 2010. Invasive rats alter woody seedling composition on seabird-dominated islands in New Zealand. Oecologia 163: 449-460.

Grubb PJ, Bellingham PJ, Kohyama TS, Piper FI, Valido A 2013. Disturbance regimes, gap-demanding trees and seed mass related to tree height in warm temperate rain forests worldwide. Biological Reviews 88: 701-744.

Gurevitch J, Padilla DK 2004. Are invasive species a major cause of extinctions? Trends in Ecology \& Evolution 19: 470-474.

Honnay O, Bossuyt B, Verheyen K, Butaye J, Jacquemyn H, Hermy M 2002. Ecological perspectives for the restoration of plant communities in European temperate forests. Biodiversity \& Conservation 11: 213-242.

Husheer SW, Allen RB, Robertson AW 2006. Suppression of regeneration in New Zealand mountain beech forests is dependent on species of introduced deer. Biological Invasions 8: 823-834.

Hutchison MAS 2008. Interactions between habitat fragmentation and invasions: factors driving exotic plant invasions in native forest remnants, West Coast, New Zealand. Unpublished PhD thesis, University of Canterbury, Christchurch. 192 p.

Jane G 1983. The impact of introduced herbivores on lowland forests in the North Island. In: Thompson K, Hodder APH, Edmonds AS eds. Lowland forests in New Zealand. Proceedings of a symposium held at the University of Waikato, Hamilton, 27-28 May 1980. Pp. 135-152.

Jepson P, Jarvie JK, MacKinnon K, Monk KA 2001. The end for Indonesia's lowland forests? Science 292: 859-861.

Kelly D, Skipworth JP 1984. Tradescantia fluminensis in a Manawatu (New Zealand) forest: II. Management by herbicides. New Zealand Journal of Botany 22: 399-402.

Kessler CC 2002. Eradication of feral goats and pigs and consequences for other biota on Sarigan Island, Commonwealth of the Northern Mariana Islands. In: Veitch CR, Clout MN eds. Turning the tide: the eradication of invasive species. Proceedings of the International Conference on Eradication of Island Invasives, Species Survival Commission No. 27. Gland, Switzerland and Cambridge, UK, IUCN - The World Conservation Union. Pp. 132-140.

King CM 2005. The handbook of New Zealand mammals. 2nd edn. Melbourne, Oxford University Press. 610 p.

Knowles B, Beveridge AE 1982. Biological flora of New Zealand 9. Beilschmiedia tawa (A. Cunn.) Benth. et Hook. F. ex Kirk (Lauraceae) Tawa. New Zealand Journal of Botany 20: 37-54.

Korhonen L, Korhonen KT, Stenberg P, Maltamo M, Rautiainen M 2007. Local models for forest canopy cover with beta regression. Silva Fennica 41: 671-685.

Krull CR, Choquenot D, Burns BR, Stanley MC 2013. Feral pigs in a temperate rainforest ecosystem: disturbance and ecological impacts. Biological Invasions 15: 2193-2204.

Lusk CH, Kaneko T, Grierson E, Clearwater M2013. Correlates 
of tree species sorting along a temperature gradient in New Zealand rain forests: seedling functional traits, growth and shade tolerance. Journal of Ecology 101: 1531-1541.

Lusk CH, Jorgensen MA, Bellingham PJ 2015. A coniferangiosperm divergence in the growth vs. shade tolerance trade-off underlies the dynamics of a New Zealand warmtemperate rain forest. Journal of Ecology 103: 479-488.

McAlpine KG, Lamoureaux SL, Westbrooke I 2015. Ecological impacts of ground cover weeds in New Zealand lowland forests. New Zealand Journal of Ecology 39: 50-60.

McAlpine KG, Howell CJ, Wotton DM 2016. Effects of tree control method, seed addition, and introduced mammal exclusion on seedling establishment in an invasive Pinus contorta forest. New Zealand Journal of Ecology 40: 302-309.

McConkey KR, Prasad S, Corlett RT, Campos-Arceiz A, Brodie JF, Rogers H, Santamaria L 2012. Seed dispersal in changing landscapes. Biological Conservation 146: 1-13.

Moles AT, Drake DR 1999. Post-dispersal seed predation on eleven large-seeded species from the New Zealand flora: a preliminary study in secondary forest. New Zealand Journal of Botany 37: 679-685.

Moles AT, Westoby M 2004. Seedling survival and seed size: a synthesis of the literature. Journal of Ecology 92:372-383.

Murphy EC 1992. The effects of a natural increase in food supply on a wild population of house mice. New Zealand Journal of Ecology 16: 33-33.

Murphy MJ, Inman-Narahari F, Ostertag R, Litton CM 2014. Invasive feral pigs impact native tree ferns and woody seedlings in Hawaiian forest. Biological Invasions 16: 63-71.

Nakagawa S, Schielzeth H 2013. A general and simple method for obtaining $R^{2}$ from generalized linear mixed-effects models. Methods in Ecology and Evolution 4: 133-142.

Overdyck E, Clarkson BD, Laughlin DC, Gemmill CEC 2013. Testing broadcast seeding methods to restore urban forests in the presence of seed predators. Restoration Ecology 21: 763-769.

R Core Team 2015. R: a language and environment for statistical computing. Version 3.2.1. Vienna, Austria, R Foundation for Statistical Computing. www.R-project.org.

Randall RP 2012. A global compendium of weeds. 2nd edn. Perth, WA, Department of Agriculture \& Food. 1107 p.

Reader R 1993. Control of seedling emergence by ground cover and seed predation in relation to seed size for some old-field species. Journal of Ecology: 169-175.

Reaser JK, Meyerson LA, Cronk Q, De Poorter M, Eldrege L, Green E, Kairo M, Latasi P, Mack RN, Mauremootoo J 2007. Ecological and socioeconomic impacts of invasive alien species in island ecosystems. Environmental Conservation 34: 98-111.

Ruscoe WA, Wilson D, McElrea L, McElrea G, Richardson SJ 2004. A house mouse (Mus musculus) population eruption in response to rimu (Dacrydium cupressinum) seedfall in southern New Zealand. New Zealand Journal of Ecology 28: 259-265.

Editorial board member: Peter Bellingham

Received 18 May 2016; accepted 26 August 2016
Ruscoe WA, Elkinton JS, Choquenot D, Allen RB 2005. Predation of beech seed by mice: effects of numerical and functional responses. Journal of Animal Ecology 74: 1005-1019.

Schulz K, Thelen C 2000. Impact and control of Vinca minor L. in an Illinois forest preserve (USA). Natural Areas Journal 20: 189-196.

Spear D, Chown SL 2009. Non-indigenous ungulates as a threat to biodiversity. Journal of Zoology 279: 1-17.

Standish RJ 2002. Experimenting with methods to control Tradescantia fluminensis, an invasive weed of native forest remnants in New Zealand. New Zealand Journal of Ecology 26: 161-170.

Standish RJ, Robertson AW, Williams PA 2001. The impact of an invasive weed Tradescantia fluminensis on native forest regeneration. Journal of Applied Ecology 38: 1253-1263.

Sullivan JJ, Timmins SM, Williams PA 2005. Movement of exotic plants into coastal native forests from gardens in northern New Zealand. New Zealand Journal of Ecology 29: $1-10$.

Timmins SM, Williams PA 1991. Weed numbers in New Zealand's forest and scrub reserves. New Zealand Journal of Ecology 15: 153-162.

Traveset A, Nogales M, Alcover JA, Delgado J, LópezDarias M, Godoy D, Igual JM, Bover P 2009. A review on the effects of alien rodents in the Balearic (Western Mediterranean Sea) and Canary Islands (Eastern Atlantic Ocean). Biological Invasions 11: 1653-1670.

Turner IM, Corlett RT 1996. The conservation value of small, isolated fragments of lowland tropical rain forest. Trends in Ecology \& Evolution 11: 330-333.

Walker S, Price R, Rutledge D, Stephens RTT, Lee WG 2006. Recent loss of indigenous cover in New Zealand. New Zealand Journal of Ecology 30: 169-177.

Wardle DA, Barker GM, Yeates GW, Bonner KI, GhaniA2001. Introduced browsing mammals in New Zealand natural forests: aboveground and belowground consequences. Ecological Monographs 71: 587-614.

Wardle J 1984. The New Zealand beeches: ecology, utilisation and management. Christchurch, New Zealand Forest Service. $447 \mathrm{p}$.

Wardle P 1991. Vegetation of New Zealand. Cambridge, UK, Cambridge University Press. 672 p.

Weller SG, Cabin RJ, Lorence DH, Perlman S, Wood K, Flynn T, Sakai AK 2011. Alien plant invasions, introduced ungulates, and alternative states in a mesic forest in Hawaii. Restoration Ecology 19: 671-680.

Williams PA, Karl BJ, Bannister P, Lee WG 2000. Small mammals as potential seed dispersers in New Zealand. Austral Ecology 25: 523-532.

Wilson DJ, Lee WG, Webster RA, Allen RB 2003. Effects of possums and rats on seedling establishment at two forest sites in New Zealand. New Zealand Journal of Ecology 27: 147-155.

Wiser SK, Allen RB 2006. What controls invasion of indigenous forests by alien plants? In: Allen RB, Lee WG eds. Biological invasions in New Zealand. Berlin, SpringerVerlag. Pp. 195-209.

Wotton DM, Kelly D 2011. Frugivore loss limits recruitment of large-seeded trees. Proceedings of the Royal Society of London B: Biological Sciences 278: doi:10.1098/ rspb.2011.0185. 
Appendix 1. Seed weights, numbers of seeds sown in the field and glasshouse, and percent germination in the glasshouse for native plant species used.

\begin{tabular}{lccccc}
\hline & \multicolumn{2}{c}{ Field } & \multicolumn{2}{c}{ Glasshouse } \\
& $\begin{array}{c}\text { Mean } \pm \text { SE seed } \\
\text { weight }(\mathrm{mg})\end{array}$ & $\begin{array}{c}\text { No. seeds sown } \\
\text { per subplot }\end{array}$ & $\begin{array}{c}\text { Total no. seeds } \\
\text { sown }\end{array}$ & $\begin{array}{c}\text { No. seeds sown } \\
\text { per tray }\end{array}$ & $\begin{array}{c}\text { Mean } \pm \text { SE } \\
\text { germination }(\%)\end{array}$ \\
\hline Beilschmiedia tawa & $1375.9 \pm 40.1^{\mathrm{a}}$ & 2 & 384 & 28 & $4.5 \pm 3.4$ \\
Vitex lucens & $370.7 \pm 10.8^{\mathrm{a}}$ & 10 & 1920 & 92 & $30.7 \pm 3.2$ \\
Hedycarya arborea & $243.4 \pm 5.9^{\mathrm{a}}$ & 10 & 1920 & 100 & 0 \\
Knightia excelsa & $28.6 \pm 0.7^{\mathrm{a}}$ & 10 & 1920 & 50 & $67.5 \pm 5.3$ \\
Coprosma grandifolia & $14.7 \pm 0.4^{\mathrm{a}}$ & 25 & 4800 & 100 & $17.5 \pm 2.5$ \\
Myrsine australis & $8.7 \pm 0.1^{\mathrm{b}}$ & 40 & 7680 & 100 & $3.3 \pm 1.0$ \\
Pseudopanax arboreus & $4.9 \pm 0.2^{\mathrm{c}}$ & 50 & 9600 & 100 & $1.0 \pm 0.4$ \\
Piper excelsum & $2.1 \pm 0.02^{\mathrm{c}}$ & 100 & 19200 & 100 & $39.3 \pm 9.6$ \\
Melicytus ramiflorus & $1.2 \pm 0.02^{\mathrm{c}}$ & 100 & 19200 & 100 & $41.5 \pm 3.9$ \\
Geniostoma ligustrifolium & $0.5 \pm 0.02^{\mathrm{d}}$ & 100 & $1.3 \pm 1.0$ \\
\hline Averag
\end{tabular}

Averages calculated from ${ }^{\mathrm{a}} 100$ seeds weighed individually, ${ }^{\mathrm{b}} 27$ lots of 40 seeds, ${ }^{\mathrm{c}} 10$ lots of 100 seeds, ${ }^{\mathrm{d}} 20$ lots of 100 seeds 